\title{
IMPACT OF FINANCING DECISIONS ON FIRM'S PERFORMANCE: AN EMPIRICAL STUDY OF PAKISTANI LISTED FIRM'S IN KSE
}

\author{
AKMAL KHAN \\ Lecturer Sargodha University Lyallpur Campus Faisalabad \\ akmal.szabist@gmail.com \\ Maria Shaikh \\ Assistant Professor-IBA-University of Sindh Jamshoro \\ Aisha Bashir Shah \\ Assistant Professor-IBA-University of Sindh Jamshoro \\ ImtiazZahid
}

Lecturer Post Graduate Islamia College Faisalabad

Dr.FaizMuhammdShaikh

Associate Professor-SZABAC-Dokri

\begin{abstract}
The basic purpose of our research paper is to analyze the impact of financing decisions on the firm's performance in Pakistani listed firms in KSE. The OLS has been employed on a sample of conveniently selected 100 pakistanilisted firms in KSE (with 600 observations) over the period of 2004 to 2009.Financing decisions are measured through debt to equity and firm's performance measured through ROE, ROA, Tobin's $Q$ and market capitalization.Ourresults show that the financing decisions have no significant impact on firm's performance in Pakistan.
\end{abstract}

Key words: Financing decisions, firm's performance, ROE, ROA and Tobin's $Q$ Introduction

Most of the firms issue bonds (debt) and equity in order to meet cash requirements at present and in future. To achieve this objective firms rebalance its capital structure by changing the proportionate of debt and equity. In this study, we examine the significance of financing decisions on firm's performance. Financing decisions concerned the use of debt and equity and firm's performance is judged through ROA, ROE, Tobin's $Q$ ratioand the value of market capitalization of the firm. Results revealed that urgent cash requirements are the main reasons for a firm to increase external finance in the form of debt and equity and firms cost of finance its timing to market and choices on the basis of trade off are main motives. Some of the most important theories relating to issuance of debt and equity on the basis of different factors are the precautionary saving theory posits that firms facing more uncertainties are more likely to issue equity rather than debt and prefer higher cash balances (Bates, Kahle, and Stulz (2009) and McLean (2011)). The static tradeoff theory emphasizes adjustment toward leverage targets. The market timing theory posits that firms issue equity when the relative cost of equity is low and issue debt when the relative cost of debt is low.One of the main theories of how firms make their financing decisions is the pecking order theory, which suggests that firms avoid external financing while they have internal financing available and avoid new equity financing while they can engage in new debt financing at reasonably low interest rates. Another major theory is the trade-off theory in which firms are assumed to trade-off the tax benefits of debt with the bankruptcy costs of debt when making their decisions. An emerging area in finance theory is right-financing whereby investment banks and corporations can enhance investment return and company value over time by determining the right investment objectives, policy framework, institutional structure, source of financing(debt or equity) and expenditure framework within a given economy and under given market conditions.

An appropriate capital structure is a critical decision for any business organization. The decision is important not only because of the need to maximize returns of the investor and owner equity, but also because of the impact such a decision has on an organizations ability to deal with its competitive environment. As we know that today's world turn into global village so companies are having very less margin to increase their return through increase in their prices whereas cost cutting is the basic formula to create a competitive edge in the competitive environment. Firms financing decision can play an important role in this regard.

We find that financing decisions have no significant impact on firm performance. When financing decisionsmeasured through debt to equity ratio and firm's performance measured through return on equity, return on assets, Tobin's $Q$ ratio and market capitalization. Which seem consistent with the perfect capital market theory of (Modigliani \& Miller, 1958).

\section{Literature Review}

An important financial decision firm's face is the choice between debt and equity capital (Glen and Pinto, 1994, cited in Joshua Abor.2007). The capital structure (or financial structure) of a firm is a specific mixture of debt and equity the firm 

uses to finance its operations. Capital structure decisions are crucial for any business organization. The decision is important because of the need to maximize returns to various organizational constituencies and also because of the impact such a decision has on an organization's ability to deal with its competitive environment (Abor and Biekpe, 2005). The key is for firms to choose a portfolio of capital structure that will maintain sustainability and generate more wealth. In general, a firm can choose among many alternative capital structures. It can issue a large amount of debt or very little debt. It can arrange lease financing, use warrants, issue convertible bonds, sign forward contracts or trade bond swaps. In an attempt to set a capital structure that maximizes overall market value, firms do differ in the way they deal with the issue of optimizing capital structure requirements (Joshua Abor, 2007).

Much of the early literature is concerned with the proposition that the market value of a firm is unaffected by its financing decisions, and most of the early proofs use arbitrage arguments. Since the existence of such opportunities is inconsistent with equilibrium in a perfect capital market, one can conclude that the market value of a firm is unaffected by its financing decisions. Examples of this approach are the original "risk class" model of Modigliani and Miller and the "states of the world" model of Jack Hirshleifer (1965, 1966).

Stiglitz (1974, Theorem 2) gives the most general arbitrage proof that Assumptions 1-5 imply that the market value of a firm is unaffected by its financing decisions. Sup- pose there is an optimal capital structure for the firm, but the firm does not choose this capital structure. Any investor can provide the optimal capital structure to the market by buying equal proportions of the firm's securities and then issuing the optimal pro- portions on personal account. If the market value of the firm were less than the value implied by an optimal capital structure, by providing the optimal capital structure to the market, the investor could earn an arbitrage profit. Since every investor has an incentive to exploit such opportunities and since exploitation is costless, their existence is inconsistent with market equilibrium. Miller show that the absence of a relationship between a firm's market value and its financing decisions does not in itself imply that the financing decisions are of no con- sequence to the firm's security holders. When the firm can issue risky debt, it may be able to use its financing decisions to shift wealth from its bondholders to its stock- holders or vice versa. Stiglitz,(1974) argues that firms are likely to maximize stock- holder wealth, even though this might be less economically efficient than maximizing combined stockholder and bondholder wealth.

In one of the few studies that included external environmental factors, Balakrishnan and Fox (1993) approached the question of capital structure from a transaction cost economics perspective. They examined the relationship between firmspecific characteristics and industry characteristics as they affected capital structure. Their finding was that firm-specific factors (R\&D, advertising, depreciation, growth opportunities, and risk) accounted for over 52 percent of the variance in capital structure. This would seem to support Barton and Gordon's (1988) contention of the relevance of managerial choice as a determinant of a firm's capital structure.

The study of different disciplines we came to this point that firm and organizations are not working in the vacuum they are suppose to interact with other factors and component in the society and economy, by integrating models from organizational economics with the strategic management literature, we are able to theorize that a firm's capital structure is influenced by environmental dynamism, and that the match between environmental dynamism and capital structure is associated with superior economic performance. Our large-scale empirical analyses provide supportive evidence for the proposition that competitive environments moderate the relationship between capital structure and economic performance. Simerl and $\mathrm{Li}(2000)$ explain very well about the financing decision they were of the point that capital structure composition of any organization is going to decide its decision making authorities that in long run works for the betterment of the firm. The same concept is validated by the study of Jensen,(1986) he said the creation of a capital structure can influence the governance structure of a firm which, in turn, can influence the ability of a firm to make strategic choices (Jensen, 1986).

The relationship between the capital structure choice and the competitive capabilities of firms have gained in importance in recent years as the global competitiveness of U.S. firms has declined (Hill, Hitt, and Hoskisson, 1988; Porter, 1992).

Modigliani and Miller (1958, 1963), viewed that an optimal capital structure exists which balances the risk of bankruptcy with the tax savings of debt. Once established, this capital structure should provide greater returns to stockholders than they would receive from an all-equity firm. However, empirical studies that have tried to probe this theoretical relationship have produced results which raise as many questions as they provide answers (Ghosh, 1992; Myers, 1984). Further, despite the apparent benefits of leverage, there are many firms that avoid significant levels of debt altogether (Gardner and Trzcinka, 1992)

Bradley, Jarrell, and Kim (1984) hypothesized that there were three firm-specific factors which would influence a firm's optimal capital structure: the variability of firm value, the potential impact of financial distress, and the level of non-debt tax shields. They found that both the volatility of firm earnings and the potential impact of financial distress had the predicted inverse relationship with firm leverage. One finding counter to theory was that there was a direct, rather than inverse, relationship between firm leverage and the relative amount of non-debt tax shields. Their definition of non-debt tax shields included firm- specific assets derived as a result of activities such as advertising and research and development. Further, they found that industry effects had a significant impact on capital structures. More specifically, they found that over 54 percent of the cross-sectional variance in firm leverage could be explained by industry classification.

Chung's (1993) study of capital structure examined the relationship between operating risk and asset characteristics. This study found that output market uncertainty (the volatility of demand) was negatively related to leverage. That is, firms which faced relatively low levels of market uncertainty, such as firms in the utility industry, will have a higher level of debt in their capital structure. It was also found that firms with greater growth opportunities, as measured by industry trends, 

tended to use less debt. In summary, the research into capital structure from a financial management perspective provides support for an argument that environmental factors could have an impact on the capital structure decision.

The features of the financial system of a country play an important role in defining the determinants of financing decisions taken by the firms of that country. Only by comparing the decisions taken by firms operating in different financial environments, can we fully analyze the effect of these institutional features. Theories about asymmetric information problems have suggested that firms should be sensitive to the providers of funds, besides whether it is in the form of debt or equity. Since different fund providers have access to different information, and have different abilities to monitor firm behavior, they will be willing to pay different prices for the securities issued by a firm.

In underdeveloped financial markets, the flotation of new issues is more difficult and costlier, since markets are less liquid and asymmetric information problems are more severe. It can be argued that in such a situation, there is a positive role for banks to act as holding companies, where the effects of the above market imperfections are minimized for two reasons. First, banks can internally allocate cash among firms belonging to their industrial group, thus, mitigating liquidity problems. Second, banks can monitor more effectively since they have access to detailed information, thereby reducing asymmetric information and agency problems (Jesus Saa-Requejo, 1996).

The capital structure of the firm could be explained, in general terms, by two dominant theories: the trade-off and pecking order theories. According to trade-off theory, optimal capital structure could be determined by balancing the different benefits and costs associated with debt financing. "Pecking order" theory suggests that firms will initially rely on internally generated funds, and then they will turn to debt if additional funds are needed and finally they will issue equity to cover any remaining capital requirements. It will cost the firm more to issue fresh equity shares than using internal funds. There is a hierarchy of firm preferences with respect to the financing of their investments. The order of preferences reflects the relative costs of various financing options (Myers \&Majluf, 1984). Small firm owners will try to meet their finance needs from a pecking order of, first, their "own" money (personal savings; retained earnings); second, short-term borrowings; third, longer term debt; and, least preferred of all, from the introduction of new equity investors, which represents the maximum intrusion (Cosh and Hughes, 1994). ). Kinsman and Newman (1999) state that examination of the relationship between capital structure choice (i.e. debt level) and firm's performance is very important for many reasons. Among these reasons: first, mean firm debt level have risen substantially over the last periods, requiring an explanation of the impact of debt level on firm's performance, so that appropriate debt level decisions can be made in a particular firm.

Second, since managers and investors may have different emphases, the relative strengths of any specific effects of debt on firm's performance must be known. Final, and most important, reason for studying debt level and firm's performance is to examine the association between debt level and shareholders wealth, since shareholders wealth maximization is a primary goal of firm's managers. Jensen and Meckling (1976) demonstrate that the amount of leverage in a firm's capital structure affects the agency conflicts between managers and shareholders by constraining or encouraging managers to act more in the interest of shareholders and, thus, can alter manager's behaviors and operating decisions, which means that the amount of leverage in capital Choice structure affects firm performance (Graham and Harvey, 2001)

Hadlock and James (2002) concluded that companies prefer loan (debt) financing because they anticipate a higher return Mesquita and Lara (2003) found in their study that the relationship between rates of return and debt indicates a negative relationship for long-term financing. However, they found a positive relationship for short-term financing and equity. Capital structure choice decision, in general terms, has a weak-to-no impact on firm's performance (Ebaid.S.E.I, 2009). Abor (2005) investigates the relationship between capital structure and profitability of listed firms in Ghana showing that STD and TTD are positively related with firm's profitability (i.e. ROE), whereas LTD is negatively related with firm's profitability (i.e. ROE). Kyereboah-Coleman (2007) examines the relationship between capital structure and performance of microfinance institutions in sub-Saharan Africa showing that high leverage is positively related with performance (i.e. ROA and ROE).

\section{Methodology}

For the smooth running of any organization the very first thing that is required is capital. Capital is financed through many different sources. It is the combination or mix of debt and equity, which company can use to finance its long term operations. There are certain costs associated with these financing decisions. The goal of the company is always to earn maximum rate of return in minimum cost. There are two types of factors that are influencing the capital structure of any organization one is internal factor and another is external factor.

The internalfactors are basically, period and objective of financing, business size, nature of business, regularity \& certainty of income, structure of assets. There are some external factors that include the policies of the financial organization, cost of financing, seasonal variation, economic fluctuation, nature of competition and most important capital market condition. The optimal and best structure is attaining on that mix of that debt and equity which maximize the value of the company and minimize the cost of the capital.

Variables: For the purpose of analysis researchers take debt to equity ratio as independent variable, and size as control variable. Size is measured in term of natural log of total assets. Dependent variables are ROE, ROA, Tobin's $Q$, and market capitalization. Return on equity (ROE) measures a corporation's profitability by revealing how much profit a company generates with the money shareholders have invested.ROA gives an idea as how efficient management is at using its assets to generate earnings. Majumdar and Chhibber,(1999) Abor, (2005) and Ebaid (2009) used the same variable in their research to measure the performance of the firm. Tobin's $Q$ was developed by James Tobin (Tobin 1969) as the ratio between the market value and replacement value of the same physical asset. Abor, (2007) and Ebaid, (2009) 
International Journal of Management and Information Technology used Tobin'q as performance measure in their studies. Market capitalization is calculated by multiplying a company's shares outstanding by the current market price of one share. Market capitalization represents the public consensus on the value of a company's equity. It provides a total value for the company's shares and thus for the company as a whole.

\section{Control variable:}

From the view of the literature the researchers identified that firm's size may influence its performance, larger firms have a greater variety of capabilities and can enjoy economies of scale, which may influence the results and the inferences ( Frank and Goyal, 2003; Jermias, 2008). As in the present study we are examining the different industries with different size, therefore this study controls the differences in firm's operating environment by including the size variable in the model. Size is measured by the natural Log of total assets of the firm and included in the model to control for effects of firm size on dependent variable that is performance.

\section{Population:}

The population of the study was all publicly traded firms listed on Karachi stock exchange during the period of 2004-2009.

\section{Sample characteristics:}

In the present research the sample size of 100 companies was taken. The data of these firms was taken from balance sheet analysis, published on the siteof State Bank of Pakistan. The firms are from the different industrial sector of Pakistan that includes Sugar, textile, Engineering, cement, tobacco, telecom, Oil and gas, Chemical.

\section{Data characteristics:}

Data was taken from 2004 to 2009. Panel data refers to multi-dimensional data. Panel data contains observations on multiple phenomena observed over multiple time periods for the same firms or individuals. In the present research the researchers observe the 100 firm over the period of 6 year.

\section{Data analysis technique:}

The data was analyzed by the application of common effect model. OLS was used to measure the impact of independent variable on the dependent variables.

\section{Results Analysis}

This chapter shows the results of Ordinary Least Square regression to test the relationship between financing decisions and firm performance. These relationships are measured by ratio of ROE, ROA, Tobin's $Q$ and Market capitalization.

Table 1

\section{Dependent variable: ROE}

$\mathrm{ROE}=\alpha+\beta_{1} \mathrm{D} / \mathrm{E}+\beta_{2}$ Size + Error

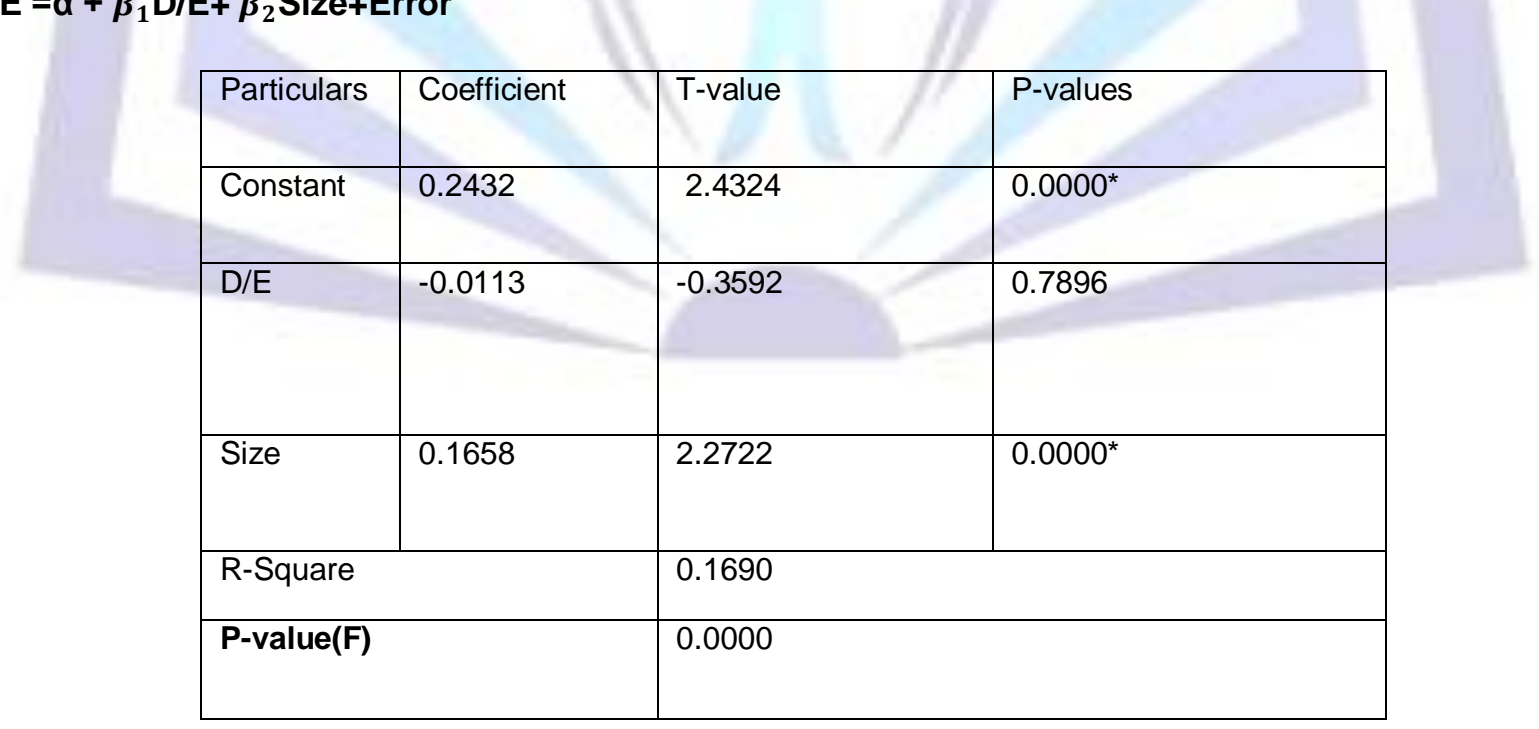

( ${ }^{*}$ significant at $1 \%$ )

Table 1 show that there is insignificant relationship between $D / E$ and $R O E$, while positive and significant relationship between size and ROE. The value of $R^{2}(0.1690)$ shows $16.90 \%$ change in ROE due to 1 unit change in D/E and size. $P$ value of $\mathrm{F}$-statistics shows model is fit at $1 \%$ level of significance. 
International Journal of Management and Information Technology Table 2

\section{Dependent variable: ROA}

\section{ROA $=\alpha+\beta_{1} D / E+\beta_{2}$ Size + Error}

\begin{tabular}{|l|l|l|l|l|}
\hline Particulars & Coefficient & T-value & P-values \\
\hline Constant & 0.1820 & 2.9347 & $0.0005^{*}$ \\
\hline D/E & -0.0001 & -1.0440 & 0.2968 \\
& & & \\
\hline Size & 0.1280 & 3.5805 & $0.0002^{\star}$ \\
& & & \\
\hline R-Square & 0.2210 & \\
\hline
\end{tabular}

(*significant at $1 \%)$

Table 2 shows that there is insignificant negative relationship is found between $D / E$ and ROA, while positive relationship between size and ROA. The value of $R^{2}(0.2210)$ shows $22.10 \%$ change in ROA due to 1 unit change in Size and D/E. Significance value of F-statistics shows model is fit at $1 \%$ level of significance.

\section{Table 3}

\section{Dependent variable:Tobin's Q}

Tobin's $Q=\alpha+\beta_{1} D / E+\beta_{2}$ Size + Error

\begin{tabular}{|l|l|l|l|}
\hline Particulars & Coefficient & T-value & P-values \\
\hline Constant & 13.1470 & 2.3450 & $0.0004^{*}$ \\
\hline D/E & 0.0011 & 0.0311 & 0.9751 \\
& & & \\
\hline Size & -0.2801 & -2.5657 & $0.0000^{*}$ \\
& & & \\
\hline R-Square & 0.1500 & \\
\hline P-value(F) & 0.0420 \\
\hline
\end{tabular}

(*significant at $1 \%)$

Table 3, shows the positiverelationship between $D / E$ and Tobin's $Q$ is not statistically significant, while the negative relationship between size and Tobin's $Q$ is statistically significant. The value of $R^{2}(0.1500)$ shows $15 \%$ change in Tobin's $Q$ due to 1 unit change in D/E and size. P-value of F-Statistics is $(0.0420)$ shows model is fit.

\section{Table 4}

\section{Dependent variable:Market Capitalization}

\section{Market Cap $=\alpha+\mathrm{D} / \mathrm{E}+$ Size+Error}

\begin{tabular}{|l|l|l|l|}
\hline Particulars & Coefficient & T-value & P-values \\
\hline Constant & 28667748 & 4.6758 & $0.0000^{*}$ \\
\hline D/E & -20738.0263 & -0.0796 & 0.9365 \\
& & & \\
\hline
\end{tabular}




\begin{tabular}{|c|c|c|c|}
\hline Size & 0.1256 & 2.0482 & $0.0000^{*}$ \\
\hline \multicolumn{2}{|c|}{ R-Square } & \multicolumn{2}{|l|}{0.2604} \\
\hline \multicolumn{2}{|c|}{ P-value(F) } & \multicolumn{2}{|l|}{0.0050} \\
\hline
\end{tabular}

Table 4, shows the relationship between D/E and market capitalization is not statistically significant, while the relationship of size and market capitalization is positive and statistically significant. The value of $R^{2}(0.2604)$ shows $26.04 \%$ change in market capitalization due to 1 unit change in D/E and size. P-value of F-Statistics(0.0050) shows model is fit.

\section{Conclusion}

In order to measure the relationship between the financing decisions and performance of the firm, various financial indicators were analyzed.ROE, ROA, Tobin's $Q$ and Market capitalization were taken as the firm's performance indicators while D/E was taken as financing decisions indicators. Based on the OLS regression estimation it was found that if a firm is highly levered its ROE will not be affected. Firms with huge assets base will have greater ROA. The market value of the firm is not affected by the financing decisions of the firm. Based on the Tobin's $Q$ ratio it is suggested that due to the new added cost of the capital the market value of the firm's assets is not affected. Firm's market capitalization (public consensus about firm's market value) is not affected by the financing decisions of the firm. The positive relationship between firm's size and capital financing indicates that Firm's with strong assets base will incur high financing cost. Itmeans that most of the assets are financed through debt.

Similar to the earlier literature it is concluded that the performanceof the firm is not affected by its financing decisions. Firm can use itsinternal funds or external funds (equity or debt) to finance its projects.

\section{Future Research Direction}

Our data sample consisted of 100 companies listed on Karachi Stock Exchange, randomly selected from different industries. The results can be further refined by increasing the sample size. The result might be different among different industries; therefore the impact of financing decisions on firm performance can be analyzed for each industry increasing the sample size.

\section{References}

1. A transition economy on an aspect of corporate governance", Public Choice, Vol. 98

A. A. Robichek, D. Teichroew, J. M. Jones, 1965. Optimal Short Term Financing Management Science, Vol. 12, No. 1, Series A, pp. 1-36 : Available Through J-store. [Accessed: 05/11/2010]

A. H. Chen and A. J. Boness, 1975. Effects of Uncertain Inflation on the Investment and Financing Decisions of a firm: The Journal of Finance, Vol. 30, No. 2, pp. 469-483 Available through J-Store [Accessed: 05/11/2010]

2. Abor, J. (2005), "The effect of capital structure on profitability: an empirical analysis of listed

3. Abor, J. (2007), "Debt policy and performance of SMEs: evidence from Ghanaian and South Africa firms", Journal of Risk Finance, Vol. 8, pp. 364-79.

4. Bajaj M., Chan Y., Dasgupta S. (1998), The Relationship between Ownership, Financing Decisions and Firm Performance: A SignalingModel, International Economic Review,39( 3),723-744: Available through Blackwell Publishing for the Economics Department of the University of Pennsylvania and Institute of Social and Economic Research. [Accessed: 05/11/2010]

5. Carpentier C., (2006). The valuation effects of long-term changes in capital structure. International Journal of Managerial Finance 2(1) 4-18.

6. Cleary S. (1999). The Relationship between Firm Investment and Financial Status: The Journal of Finance. 54(2) 673-692. Available through Blackwell Publishing [Accessed: 05/11/2010]

7. David B. and Julie A. (1997), Financing the German "Mittelstand" Small Business Economics, 9(2) 97-11 [Accessed: 05/11/2010]

8. Ebaid I. E., (2009). The impact of capital-structure choice on firm performance: empirical evidence from Egypt. The Journal of Risk Finance, 10 (5), 477-487.

9. Eugene F. Fama, 1978. The Effects of a Firm's Investment and Financing Decisions on the Welfare of Its Security Holders Author: The American Economic Review, Vol. 68, No. 3, pp. 272: Available through J-stor Data Base [accessed 05/11/2010]

10. Financial Management, 25( 2) 37-51 Avalaiable through Blackwell Publishing. [Accessed: 05/11/2010]

11. Firms in Ghana", Journal of Risk Finance, Vol. 6, pp. 438-47.

12. Majumdar, S. and Chhibber, P. (1999), "Capital structure and performance: evidence from

13. McConaughy D.L., and Mishra C., (1996). Debt, Performance-Based Incentives, and Firm Performance.

14. Modigliani, F., \& Miller, M. H. (1958). The Cost of Capital, Corporation Finance and the Theory of Investment. The American Economic Review, pp. 261-297.

15. N.A (2005).Comparison of debt financing between international and domestic firms, Evidence from Turkey, Germany and UK HalitGonenc. International Journal of Managerial Finance 1(1) 49-68. 
nternational Journal of Management and Information Technology 16. Neil Seitz, 1982. Shareholder Goals, Firm Goals and Firm Financing Decisions: Financial Management, Vol. 11, No. 3, pp. 20-26 Available through J-store. [Accessed: 05/11/2010]

17. pp. 287-305.

18. Robert A. Taggart, Jr, 1977. A Model of Corporate Financing Decisions: The Journal of Finance, Vol. 32 , No. 5 pp. 1467-1484 Available through : j-store Data Base. [Accessed: 05/11/2010]

19. Robert T. (1998). International Journal of Entrepreneurial Behavior \& Research, 4(3), 239-248.

20. Roy L. Simerly and Mingfang Li, 2000. Environmental Dynamism, Capital Structure and Performance: A Theoretical Integration andan Empirical Test: Strategic Management Journal, Vol. 21, No. 1 pp. 31-49: Available through [Accessed: 05/11/2010]

21. Saá-Requejo J.( 1996) Financing Decisions: Lessons from the Spanish Experience. Financial Management 25(3) 44-56. Available through Blackwell Publishing [Accessed: 05/11/2010]

22. SrinivasanBalakrishnan and Isaac Fox, 1993.Asset Specificity, Firm Heterogeneity and Capital Structure: Strategic Management Journal, Vol. 14, No. 1, pp. 3-16: Available Through J-store [Accessed: 05/11/2010]

23. Steven Fazzari, R. Glenn Hubbard, Bruce Petersen, 1988. Investment, Financing Decisions, and Tax Policy The American Economic Review, Vol. 78, No. 2, pp. 200-205: Available Through J-store. [Accessed 05/11/2010]

24. Venkat Subramanian, 1998. Efficient Sourcing and Debt Financing in Imperfect Product Markets: Management Science, Vol. 44, No. 9, pp. 1167-1178: Available through J-store. [Accessed: 05/11/2010].

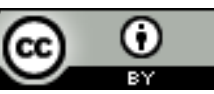

This work is licensed under a Creative Commons Attribution 4.0 International License.

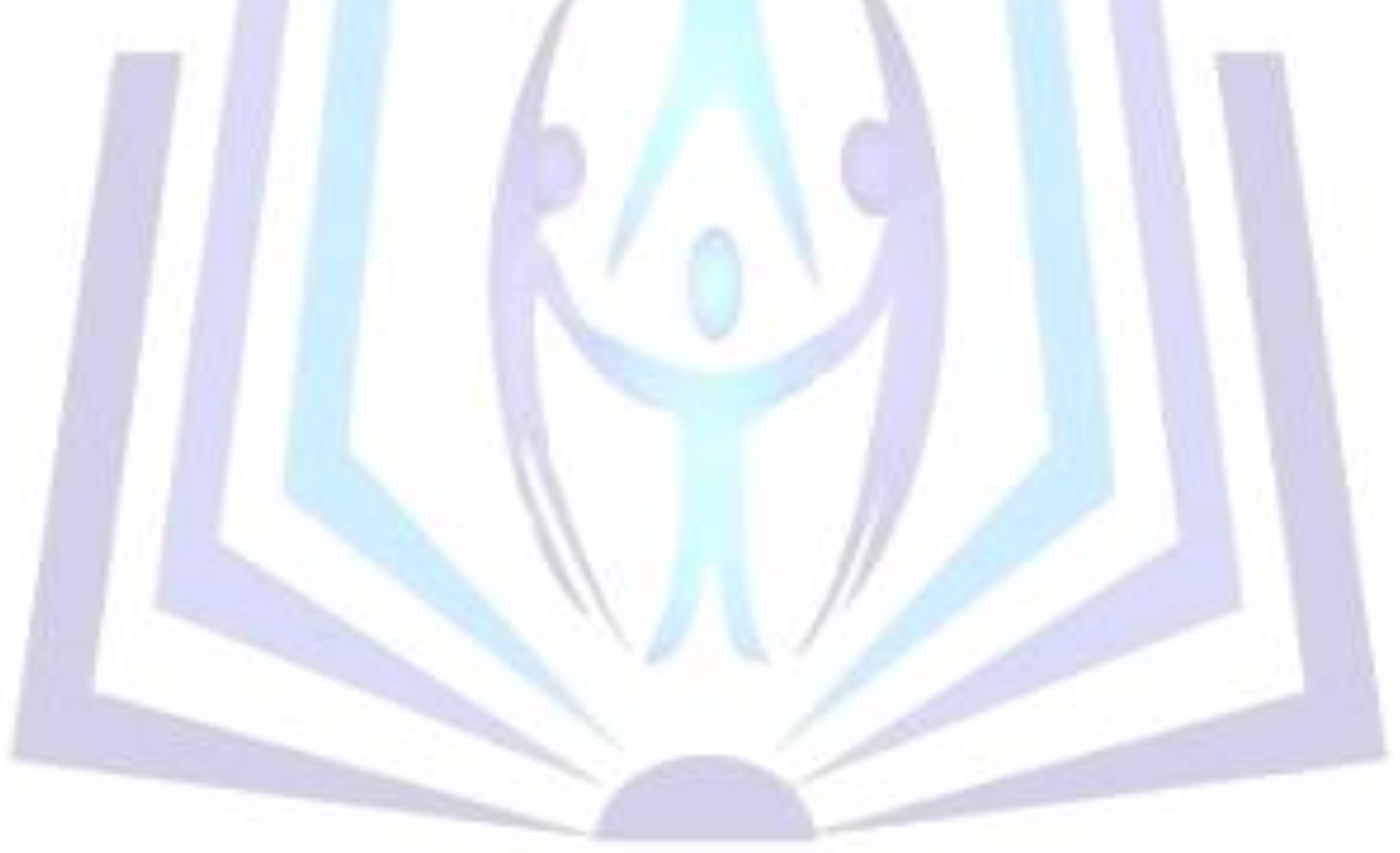

